\title{
TU/e EmonONEN

\section{The pitfalls of prosopography: inventors in the dictionary of national biography}

Citation for published version (APA):

MacLeod, C., \& Nuvolari, A. (2006). The pitfalls of prosopography: inventors in the dictionary of national biography. Technology and Culture, 47(4), 757-776. https://doi.org/10.1353/tech.2006.0240

DOI:

10.1353/tech.2006.0240

Document status and date:

Published: 01/01/2006

\section{Document Version:}

Publisher's PDF, also known as Version of Record (includes final page, issue and volume numbers)

\section{Please check the document version of this publication:}

- A submitted manuscript is the version of the article upon submission and before peer-review. There can be important differences between the submitted version and the official published version of record. People interested in the research are advised to contact the author for the final version of the publication, or visit the $\mathrm{DOI}$ to the publisher's website.

- The final author version and the galley proof are versions of the publication after peer review.

- The final published version features the final layout of the paper including the volume, issue and page numbers.

Link to publication

\section{General rights}

Copyright and moral rights for the publications made accessible in the public portal are retained by the authors and/or other copyright owners and it is a condition of accessing publications that users recognise and abide by the legal requirements associated with these rights.

- Users may download and print one copy of any publication from the public portal for the purpose of private study or research.

- You may not further distribute the material or use it for any profit-making activity or commercial gain

- You may freely distribute the URL identifying the publication in the public portal.

If the publication is distributed under the terms of Article 25fa of the Dutch Copyright Act, indicated by the "Taverne" license above, please follow below link for the End User Agreement:

www.tue.nl/taverne

Take down policy

If you believe that this document breaches copyright please contact us at:

openaccess@tue.nl

providing details and we will investigate your claim. 


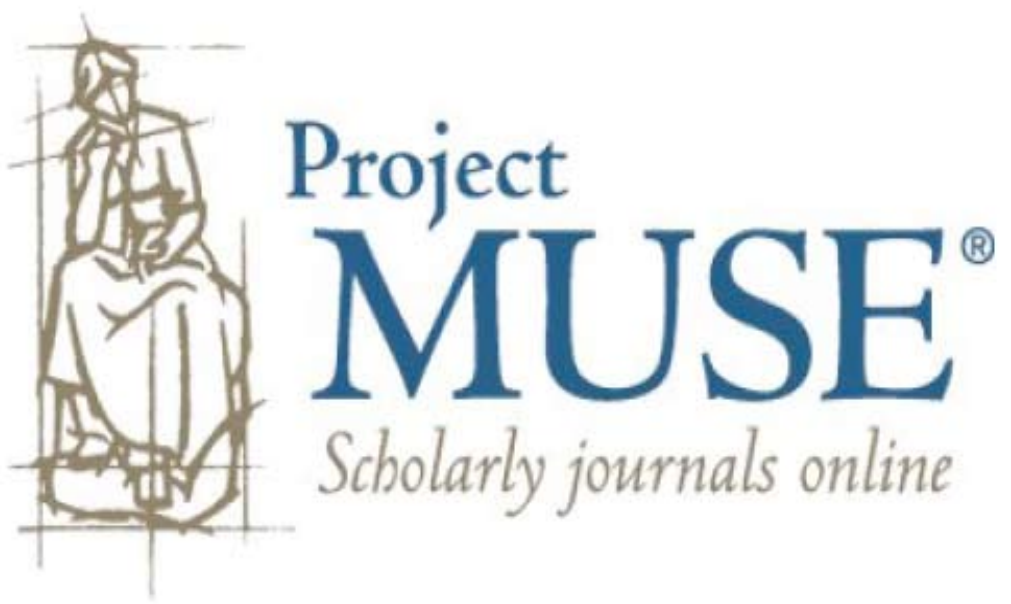




\title{
The Pitfalls of Prosopography
}

\author{
Inventors in the Dictionary of National Biography
}

\author{
CHRISTINE MACLEOD and \\ ALESSANDRO NUVOLARI
}

The Dictionary of National Biography was a triumph of Victorian literary engineering and private enterprise. Its original sixty-three volumes contained 29,120 entries. ${ }^{1}$ They were produced in "eighteen years of unremitting labour" between 1882 and 1900, and published at the formidable rate of one volume every three months (precisely). ${ }^{2}$ The Dictionary (henceforward $D N B$, as it is affectionately known in Britain) was intended to provide "full, accurate, and concise biographies of all noteworthy inhabitants of the British Islands and the Colonies (exclusive of living persons) from the earliest historical period to the present time." ${ }^{3}$

Christine MacLeod is senior lecturer in economic and social history at the University of Bristol. Alessandro Nuvolari is assistant professor in the economics of science and technology at Eindhoven University of Technology. They thank Anna Guagnini, Johan Schot, Richard Langlois, Mark Curtoys, A. P. Woolrich, and Nicoletta Corrocher, as well as the editor and the three anonymous referees of $T \bowtie C$ for their helpful comments on previous drafts. The financial support of the Netherlands Organization for Scientific Research-British Council Partnership Programme in Science (grant number PPS 833) and of the Arts and Humanities Research Council (award number RL/AN11100/APN 17938) is gratefully acknowledged.

(C2006 by the Society for the History of Technology. All rights reserved. 0040-165X/06/4704-0003\$8.00

1. Leslie Stephen, ed., Dictionary of National Biography (London, 1885-1900). This rises to 30,378 entries in the Concise Dictionary of National Biography, since it includes those in the two supplements, published in 1903, that contained people who had died since the DNB began publication in 1885 .

2. [Sidney Lee], "The Dictionary of National Biography, a Statistical Account," in Dictionary of National Biography, vol. 63 (London, 1900), v; David Cannadine, "British Worthies," London Review of Books, 13-16 December 1981, 3-6. For a useful summary of the publishing history of the DNB, see Robert Faber and Brian Harrison, "The Dictionary of National Biography: A Publishing History," in Lives in Print: Biography and the Book Trade from the Middle Ages to the 21st Century, ed. Robin Myers, Michael Harris, and Giles Mandelbrote (London, 2002), 171-92.

3. Lee's memoir of George Smith, cited in Colin Matthew, "The New DNB," History 
In order to investigate the representation in the $D N B$ of inventors and inventive activities during the British Industrial Revolution, we have constructed a data-set of all individuals born during the period 1650-1850 whose entry credits them with at least one invention. These individuals number 383 and account for slightly more than 1 percent of all original entries. ${ }^{4}$ If this seems a small proportion, we need to remember the inclu-

OCTOBER

2006

VOL. 47 siveness of the enterprise and "the rich tapestry of British history" that the $D N B$ represented. ${ }^{5}$ It was the editors' goal to include all those who had achieved distinction in "any walk of life"; their list of examples mentioned "inventor" sixth, after "statesman, lawyer, divine, painter, author." ${ }^{6}$ Certainly, if the $D N B$ had been compiled a century earlier, the representation of inventors (as well as engineers and scientists) would have been negligible. The high regard in which inventors and engineers were held in Victorian Britain was a novel phenomenon that peaked during the second half of the nineteenth century. The men who selected the entries for the original $D N B$ grew up in a society that celebrated the achievements of the inventor and the engineer in literature, museums, and public art as never before or since. ${ }^{7}$ The second half of the nineteenth century began with the Great Exhibition in the Crystal Palace and ended with the unprecedented elevation to the peerage of such inventors and engineers as Joseph (Baron) Lister, Samuel Cunliffe Lister (who took the title Baron Masham), William (Baron) Armstrong, and William Thomson (Baron Kelvin). It witnessed the erection of statues in city centers and major public buildings to men such as these and other inventors, and saw the opening in South Kensington of the Patent Office Museum (later part of the Science Museum), which attracted 4.5 million visitors between 1855 and $1878 .{ }^{8}$ The period was

Today, 10-13 September 1993, 10. See also Keith Thomas, Changing Conceptions of National Biography: The Oxford DNB in Historical Perspective (Cambridge, 2005), 27.

4. A list of these inventors and the database for this article may be requested from the authors.

5. R. A. Buchanan, The Engineers: A History of the Engineering Profession in Britain, 1750-1914 (London, 1989), 21-22. Buchanan identified 489 engineers in the DNB; there is some overlap with our set of 383 inventors. For a shortfall in Fellows of the Royal Society, see J. H. Appleby, "A New Lease of Life for 71 Missing Fellows," Notes \& Records of the Royal Society of London 48 (1994): 121-25.

6. [Lee], viii. The editors of the $D N B$ estimated that their entries represented one in every 5,000 adults inhabiting the British Isles since Roman times, or one in every 10,000 infants born there. For the principles of inclusion followed by the original $D N B$ and the new Oxford Dictionary of National Biography (Oxford, 2004), as well as the DNB's notorious shortfalls in certain categories (including women, businessmen, trade-union leaders, and other working-class people), see http://www.oup.com/oxforddnb/info/prelims/intro/intro2/, accessed 31 May 2006.

7. Christine MacLeod, Heroes of Invention: Reputation and Industrial Culture in Nineteenth-Century Britain (Cambridge, 2007 [forthcoming]).

8. Ian Inkster, "Patents as Indicators of Technological Change and Innovation: An Historical Analysis of the Patent Data, 1830-1914," Transactions of the Newcomen Society 73 (2003): 179-208, esp. 199. 
awash with biographical studies, of which those produced by Samuel Smiles represented only the tip of a publishing iceberg.

The aim of this article is to scrutinize the criteria adopted by the Victorian edition of the $D N B$ when selecting British inventors born during the period 1650-1850. ${ }^{9}$ We work with this first edition in order to interrogate the late Victorians' conceptualization of invention and its influence on successive narratives of the British Industrial Revolution. Simultaneously, we seek to raise methodological issues about the selection of historical sources for prosopographical studies.

This is a timely exercise for two reasons. First, the new Oxford Dictionary of National Biography (ODNB), while revising the original entries, includes them all: there have been additions, but no deletions. ${ }^{10}$ Consequently, the Victorians' notion of why an inventor merited inclusion in this definitive national pantheon will, to some extent, continue to inform the twenty-first century's concept of the inventor, especially since its machinereadable format will make the new $O D N B$ an attractive source for prosopographers. $^{11}$

Second, a prosopographical approach to the history of technology raises fundamental methodological issues that, as we shall see, seem to have been insufficiently appreciated in several recent contributions. A particularly terse definition of prosopography has been provided by Lawrence Stone: "Prosopography is the investigation of the common background characteristics of a group of actors in history by means of a collective study of their lives." ${ }^{12}$ Nowadays, the term is chiefly used in classics or ancient his-

9. The $D N B$ was used by Merton to study the changing attitudes of English elites toward science and technology during the seventeenth century; by Hans and Birse to study, respectively, the educational backgrounds of 680 scientists born between 16001785 , and 498 notable applied scientists and engineers active during 1700-1859; and by Bendix to study the social origins of the most prominent British entrepreneurs between 1750-1850. See Robert K. Merton, Science, Technology, and Society in Seventeenth Century England (1938; reprint, New York, 1970); Nicholas A. Hans, New Trends in Education in the Eighteenth Century (London, 1951), 31-36; Ronald M. Birse, Engineering at Edinburgh University, 1673-1983 (Edinburgh, 1983), 16; and Reinhard Bendix, Work and Authority in Industry (New York, 1956), 24. None of these studies dealt in depth with the possible biases of this source.

10. See the $O D N B$ website; this new edition contains more than 50,000 entries (both hard copy and online). A preliminary, less systematic attempt at filling the gaps in the first edition and its decennial supplements was made in the 1980s; see Christine S. Nicholls, ed., The "Dictionary of National Biography": Missing Persons (Oxford, 1993). This volume contains entries for 1,086 individuals, among whom we have identified sixty-seven inventors (born between 1650-1850) absent from the Victorian edition.

11. The built-in search engine of the online edition should be used carefully. A search of the field "Technology" made on 3 November 2005 for individuals active during 1650-1850 did not produce James Watt, Richard Trevithick, James Nasmyth, Henry Cort, Matthew Murray, or Arthur Woolf.

12. Lawrence Stone, "Prosopography," Daedalus 100 (1971): 46-79. This paper contains a thorough discussion of the merits and limitations of prosopography as a method of historical investigation. In the economic history of the British Industrial Revolution, 
OCTOBER

2006

VOL. 47 tory; in other fields, the approach may be referred to as "group biography," "career-path analysis," and so on. Its aim is to identify significant variables affecting behaviors and actions of specific social groups by means of the systematic examination of representative samples. As Stone predicted, by permitting the construction and manipulation of large data-sets, progress in computing technologies has greatly enlarged the domain of prosopographical studies.

It is perhaps surprising that both individualist and social-determinist views of invention are represented in the application of prosopography to the history of technology. From the individualist approach, prosopography offers a straightforward route from individual biography to the analysis of the background characteristics of the key group of individuals responsible for technological breakthroughs. Simultaneously, it permits an important expansion of that group to include other, less famous individuals - though information about them is harder to find. Thus, O'Brien, Griffiths, and Hunt analyzed a data-set of people (identified through a wide-ranging trawl of published and archival sources) who were responsible for nearly 2,500 inventions in the textile industries between 1688 and 1851 in order to discover whether this collectivity of inventors shared any noteworthy peculiarities of "education, birth, scientific orientation, or entrepreneurial acumen." ${ }^{13}$

By contrast, the determinist approach seeks to detect the specific impact of various contextual factors on inventive activity. The most influential studies are probably those undertaken by Khan and Sokoloff. ${ }^{14}$ Their

there has been a number of prosopographical investigations of the social origins and cultural and religious backgrounds of industrialists active during this period: see, among others, Everett E. Hagen, On the Theory of Social Change (London, 1962), chap. 13; Katrina Honeyman, Origins of Enterprise: Business Leadership in the Industrial Revolution (Manchester, 1982); and François Crouzet, The First Industrialists (Cambridge, 1985).

13. Some preliminary findings of this exercise are reported in Patrick O'Brien, Trevor Griffiths, and Philip Hunt, "Technological Change during the First Industrial Revolution: The Paradigm Case of Textiles, 1688-1851," in Technological Change, ed. Robert Fox (Amsterdam, 1996); and in Patrick O’Brien, Trevor Griffiths, and Philip Hunt, "Theories of Technological Progress and the British Textile Industry from Kay to Cartwright," Revista de Historia Economica 14 (1996): 40-67. The historical significance of individual inventors is particularly emphasized in Patrick O'Brien, "The MicroFoundations of Macro-Invention: The Case of the Reverend Edmund Cartwright," Textile History 28 (1997): 201-33. For a survey of similar prosopographical projects in the history of science, see Lewis Pyenson, "Who the Guys Were': Prosopography in the History of Science," History of Science 15 (1977): 155-88. For reflections on the prosopographical method in the history of science and information about the biographical materials available in published sources, see Steven Shapin and Arnold Thackray, "Prosopography as a Research Tool in History of Science: The British Scientific Community, 1700-1900," History of Science 12 (1974): 1-28; and William Clark, "The Pursuit of the Prosopography of Science," in The Cambridge History of Science, vol. 4, ed. Roy Porter (Cambridge, 2003), 211-37.

14. B. Zorina Khan and Kenneth L. Sokoloff, “'Schemes of Practical Utility': Entrepreneurship and Innovation among the 'Great Inventors' in the United States, 1790- 
point of departure, which reflects Jacob Schmookler's perception of inventive activity as highly responsive to economic stimuli, is far from any heroic view of technological change. ${ }^{15}$ Khan and Sokoloff challenge the heroicindividualist view of invention that, by regarding major technological breakthroughs as the products of strokes of genius and flashes of insight (or, in some cases, of serendipity or accident), denies any connection with everyday economic activities. In particular, they explore Mokyr's distinction between such exogenous macro-inventions and the endogenous micro-inventions that occur in response to perceived market signals. ${ }^{16} \mathrm{By}$ comparing their sample of "great inventors" with American patentees in general, Khan and Sokoloff demonstrate that there was no major distinction between the two groups in their sensitivity to market signals. Indeed, contrary to Mokyr's model, the "great inventors" were distinguished by their entrepreneurial abilities: if anything, they seem to have been more finely attuned than the average patentee to economic incentives. ${ }^{17}$ Thus, although Khan and Sokoloff's methodology leads them to resurrect the "great inventor" (carefully imprisoned in inverted commas), their results imply his immediate reinterment.

While not questioning their specific conclusions, we are concerned that Khan and Sokoloff treat the selection of their "great inventors" as unproblematic, and risk the perpetuation of their sources' particular notions about inventors and inventions. Their sample of "great inventors" active in the United States during the nineteenth century is drawn by identifying all those individuals credited with at least one major invention in a number of American biographical dictionaries. ${ }^{18}$ They state only that

1865," Journal of Economic History 53 (1993): 289-307; and B. Zorina Khan and Kenneth L. Sokoloff, "Institutions and Democratic Invention in 19th-Century America: Evidence from 'Great Inventors,' 1790-1930," American Economic Review 94 (2004): 395401. These studies are part of a larger research program assessing the role of the patent system in American industrialization; for an overview, see B. Zorina Khan and Kenneth Sokoloff, “The Early Development of Intellectual Property Institutions," Journal of Economic Perspectives 15 (2001): 233-46.

15. Jacob Schmookler, Invention and Economic Growth (London, 1966).

16. "Macro-inventions ... do not seem to obey obvious laws, do not necessarily respond to incentives, and defy most attempts to relate them to exogenous economic variables. Many of them resulted from strokes of genius, luck or serendipity. Technological history, therefore, retains an unexplained component that defies explanation in purely economic terms. In other words, luck and inspiration mattered, and thus individuals made a difference" (Joel Mokyr, The Lever of Riches: Technological Creativity and Economic Progress [Oxford, 1990], 13; see also 295); and Donald Cardwell, The Fontana History of Technology (London, 1994), esp. 496-501.

17. Khan and Sokoloff, "'Schemes of Practical Utility," 290.

18. Khan and Sokoloff's samples of American inventors comprise 160 individuals for 1790-1865 and 409 individuals (408 men and one woman) for 1790-1930; see, respectively, "'Schemes of Practical Utility"” and "Institutions and Democratic Invention." 
The main source ... was volumes 1 to 10 of the Dictionary of American Biography. This was supplemented by Who Was Who in America, Historical Volume, 1607-1896 and The National Cyclopaedia of American Biography; additional details were obtained from a number of biographical sources. The sample comprises vir-tually all the bestknown antebellum inventors who were active in the field of invention between 1790 and $1846 .^{19}$

2006

VOL. 47

We contend that valuable exercises such as Khan and Sokoloff's should go hand-in-hand with a critical reflection on the selection criteria followed by the compilers of the collective biographies that furnish the source materials for this type of prosopographical exercise. Prima facie, it seems unlikely that iconic works of collective biography such as the Dictionary of American Biography or the DNB will provide a random or representative sample of inventors. Consequently, a detailed inquiry into the criteria governing the selection of entries should be a compulsory research step. As Bowker and Star contend, without an awareness of the way in which classifications are initially made, our analyses are subject to distortion by a hidden but powerful "infrastructure of knowledge." ${ }^{20}$ Thus, the evidence from the selection criteria adopted by biographical dictionaries is itself revealing and, if properly handled, may be treated as a resource rather than a limitation of this type of materials. As we will show, the representation of inventive activity in the DNB starkly encapsulates various Victorian assumptions of who inventors were and what constituted an invention.

\section{Inventors and the $D N B$}

The $D N B$ was the brainchild of a philanthropic publisher, George M.

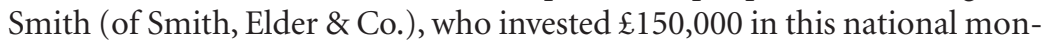
ument to "their ancestors' collective achievement." ${ }^{21}$ Smith chose the eminent literary critic and historian of ideas Leslie Stephen as his first editor. ${ }^{22}$ Stephen's method of selecting the DNB's subjects was described by Sidney Lee, his assistant editor and successor. ${ }^{23}$ His primary list

19. Khan and Sokoloff, "'Schemes of Practical Utility" (n. 14 above), 305-6.

20. Geoffrey C. Bowker and Susan Leigh Star, Sorting Things Out: Classification and its Consequences (Cambridge, Mass., 1999).

21. [Lee] (n. 2 above), xxii.

22. Bill Bell, Oxford Dictionary of National Biography (n. 6 above), s.v. "Smith, George Murray (1824-1901).” For Stephen (1832-1904), see Noel Annan, Leslie Stephen: The Godless Victorian (London, 1984); and Alan Bell, "Leslie Stephen and the Dictionary of National Biography," Times Literary Supplement, 16 December 1977, 1478.

23. Lee (1859-1926) — appointed assistant editor in 1883, joint-editor with Stephen in 1890, and sole editor (when Stephen retired, exhausted by his labors) in 1891—was 
comprised all names that had hitherto been treated in independent works of biography, in general dictionaries, in collections of lives of prominent members of various classes of the community, and in obituary notices in the leading journals and periodicals. ${ }^{24}$

Recognizing, however, that it omitted many equally important names, which "it was the special province of a new and complete Dictionary to supply," Stephen and his assistants explored "a wide field of historical and scientific literature" and surveyed "the most miscellaneous records and reports of human effort." 25

Stephen printed the proposed entries for each volume in The Athenaeum, inviting its readers to suggest additions, corrections, and criticismsan invitation that some accepted with gusto. The Athenaeum, founded in 1828 and published weekly at the astonishingly low price of $3 \mathrm{~d}$ (18611914 ), had a circulation of over 20,000 . Not only did it enjoy a reputation for "fair-minded authoritative criticism" in the fields of literature and the fine arts, but it also prided itself on making the latest scientific theories and technological developments comprehensible to a lay audience through the pens of some of "the greatest scientists of the day as regular correspondents and staff writers." ${ }^{26}$ Hence the selection rested ultimately with the upper echelons of British society: mostly male and university-educated, probably members of the liberal professions, gentlemanly capitalists, or recipients of a private income. ${ }^{27}$ While grounded primarily in the humanities, they had received some exposure to science and technology.

Stephen and Lee were among the most voluminous contributors, but in so far as possible they allocated the entries to "experts ... in their special field of study." ${ }^{28}$ Our 383 inventors were memorialized by both specialists and generalists, the majority of whom wrote fewer than five entries. ${ }^{29}$ Distinguished contributors included three Fellows of the Royal Society: Sir Frederick Bramwell (James Watt), Professor A. H. Church (Josiah Wedgwood), and Professor Silvanus Thompson (Sir Charles Wheatstone and Lord Kelvin). ${ }^{30}$ Overall, the

responsible for the final thirty-seven volumes ([Lee], vii, ix). On the work of the editors of the DNB, see Brian Harrison, "'A Slice of Their Lives': Editing the DNB, 1882-1999," English Historical Review 109 (2004): 1179-201.

24. [Lee], vii; see also Thomas (n. 3 above), 25.

25. [Lee], vii.

26. Leslie A. Marchand, "The Athenaeum": A Mirror of Victorian Culture (Chapel Hill, N.C., 1941), 12-13, 52-54, 81-82, 89-94.

27. Thomas, 20-21.

28. [Lee] (n. 2 above), xv, xviii.

29. The most prolific contributor, with forty entries, was R. B. Prosser (1838-1918), the author of a carefully researched book on Birmingham inventors (most of whom were not included in the DNB); see Richard B. Prosser, Birmingham Inventions and Inventors (1881; reprint, Wakefield, York., 1970).

30. [Lee], xvii, $\mathrm{xx}-\mathrm{xxi}$; Gillian Fenwick, The Contributors' Index to the "Dictionary of National Biography" (Winchester, Hants., 1989), 321, 404. 
contributors were a remarkable group of Victorian intellectuals with, in many cases, a sound knowledge of technological developments. Although less didactic than Samuel Smiles's tales of invention, their memoirs reflected the intellectual climate of the time, particularly the idealized connection between heroic invention and the Industrial Revolution.

What brought an inventor to the attention of the dictionary's compil-

OCTOBER

2006

VOL. 47 ers? Gender is quickly dealt with. Our list of 383 inventors comprises only men. ${ }^{31}$ It was not that women did not invent: researchers have identified sixty-two patents registered in women's names in the United Kingdom between 1617 and 1852, and a further 178 between 1853 and 1884; the share of female patentees peaked in 1894 at 2.4 percent. $^{32}$ There is a growing literature on why women struggle to be recognized as inventors. ${ }^{33}$ As we shall see, the compilers' omission of female inventors (itself symptomatic of the gender bias that permeates the DNB) also stems from a bias against inventions produced in specific technological fields.

Another critical factor was timing, which was influenced by the perceived chronology of the Industrial Revolution. We have divided our sample of inventors into four birth cohorts, each of fifty years. As may be seen in the final row of table 1 , a disproportionate number (169, corresponding to a share of 44.1 percent) belonged to the third cohort (1751-1800), which was mostly active in the "classic period" of the Industrial Revolutionnamely, 1760-1830. ${ }^{34}$ Accordingly, it includes the principal characters in the grand technological narratives of the British Industrial Revolution: for example, Samuel Crompton (1753-1827), William Murdock (1754-1839), Thomas Telford (1757-1834), George Stephenson (1781-1848), Henry

31. Only 4 percent of all entries in the first edition treated women; see J. Schneider, "Class Origin and Fame: Eminent English Women," American Sociological Review 5 (1940): 700-712. On this and other recognized biases of the original edition of the DNB, see Matthew (n. 3 above), 12-13; and Thomas (n. 3 above), 45-47. The Missing Persons volume edited by Nicholls (n. 10 above) contains two female inventors from this period: Eleanor Coade (1733-1821), inventor and manufacturer of "Coade stone," a weatherresistant ceramic body sculpted to decorate buildings, and Henrietta Vansittart (18331883), whose patented screw-propeller was fitted to many warships and liners.

32. Autumn Stanley, Mothers and Daughters of Invention: Notes for a Revised History of Technology (Metuchen, N.J., 1993), 495, 758-59; Stephen van Dulken, British Patents of Invention, 1617-1977: A Guide for Researchers (London, 1999), 84.

33. See, for example, Judith McGaw, "Inventors and Other Great Women: Toward a Feminist History of Technological Luminaries," Technology and Culture 38 (1997): 21431; Autumn Stanley, "Once and Future Power: Women as Inventors," Women's Studies International Forum 15 (1992): 193-202; and Susan McDaniel, Helene Cummins, and Rachelle Spender Beauchamp, "Mothers of Invention? Meshing the Roles of Inventor, Mother and Worker," Women's Studies International Forum 11 (1988): 1-12.

34. D. C. Coleman, Myth, History, and the Industrial Revolution (London, 1992), 30; David Cannadine, "The Past and the Present in the English Industrial Revolution, 18801980," Past and Present 103 (1984): 131-72; T. S. Ashton, The Industrial Revolution, 17601830 (Oxford, 1957). 
TABLE 1

Patents Held by All Patentees and by the Inventors in the DNB

\begin{tabular}{|c|c|c|c|c|c|c|}
\hline $\begin{array}{c}\text { Number } \\
\text { of } \\
\text { patents }\end{array}$ & $\begin{array}{c}\text { All } \\
\text { patentees } \\
(1751-1852) \\
(\%)\end{array}$ & $\begin{array}{c}\text { DNB } \\
\text { Total sample } \\
(1650-1850) \\
(\%)\end{array}$ & $\begin{array}{c}\text { DNB } \\
\text { Birth cohort } \\
(1650-1700) \\
(\%)\end{array}$ & $\begin{array}{c}\text { DNB } \\
\text { Birth cohort } \\
(1701-1750) \\
(\%)\end{array}$ & $\begin{array}{c}\text { DNB } \\
\text { Birth cohort } \\
(1751-1800) \\
(\%)\end{array}$ & $\begin{array}{c}\text { DNB } \\
\text { Birth cohort } \\
(1801-1850) \\
(\%)\end{array}$ \\
\hline 0 & - & $\begin{array}{c}151 \\
(39.43)\end{array}$ & $\begin{array}{c}19 \\
(67.86)\end{array}$ & $\begin{array}{c}29 \\
(40.28)\end{array}$ & $\begin{array}{c}68 \\
(40.24)\end{array}$ & $\begin{array}{c}35 \\
(30.7)\end{array}$ \\
\hline $\begin{array}{c}\text { Alleged } \\
\text { patentees }(D N B)\end{array}$ & - & $\begin{array}{c}31 \\
(8.09)\end{array}$ & $\begin{array}{c}0 \\
(0)\end{array}$ & $\begin{array}{c}0 \\
(0)\end{array}$ & $\begin{array}{c}2 \\
(1.18)\end{array}$ & $\begin{array}{c}29 \\
(25.44)\end{array}$ \\
\hline 1 & $\begin{array}{c}6,100 \\
(73.49)\end{array}$ & $\begin{array}{c}70 \\
(18.28)\end{array}$ & $\begin{array}{c}6 \\
(21.43)\end{array}$ & $\begin{array}{c}20 \\
(27.78)\end{array}$ & $\begin{array}{c}28 \\
(16.57)\end{array}$ & $\begin{array}{c}16 \\
(14.04)\end{array}$ \\
\hline $2-5$ & $\begin{array}{c}1,957 \\
(23.58)\end{array}$ & $\begin{array}{c}74 \\
(19.32)\end{array}$ & $\begin{array}{c}3 \\
(10.71)\end{array}$ & $\begin{array}{c}18 \\
(25)\end{array}$ & $\begin{array}{c}37 \\
(21.89)\end{array}$ & $\begin{array}{c}16 \\
(14.04)\end{array}$ \\
\hline $6-10$ & $\begin{array}{c}190 \\
(2.29)\end{array}$ & $\begin{array}{c}33 \\
(8.62)\end{array}$ & $\begin{array}{c}0 \\
(0)\end{array}$ & $\begin{array}{c}2 \\
(2.78)\end{array}$ & $\begin{array}{c}20 \\
(11.83)\end{array}$ & $\begin{array}{c}11 \\
(9.65)\end{array}$ \\
\hline$>10$ & $\begin{array}{c}54 \\
(0.65)\end{array}$ & $\begin{array}{c}24 \\
(6.27)\end{array}$ & $\begin{array}{c}0 \\
(0)\end{array}$ & $\begin{array}{c}3 \\
(4.17)\end{array}$ & $\begin{array}{c}14 \\
(8.28)\end{array}$ & $\begin{array}{c}7 \\
(6.14)\end{array}$ \\
\hline TOTAL & $\begin{array}{l}8,301 \\
(100)\end{array}$ & $\begin{array}{c}383 \\
(100)\end{array}$ & $\begin{array}{c}28 \\
(100)\end{array}$ & $\begin{array}{c}72 \\
(100)\end{array}$ & $\begin{array}{c}169 \\
(100)\end{array}$ & $\begin{array}{c}114 \\
(100)\end{array}$ \\
\hline
\end{tabular}

Note: Percentage shares are given in parentheses. Column 2 ("All patentees") is taken from H. I. Dutton, The Patent System and Inventive Activity during the Industrial Revolution, 1750-1852 (Manchester, 1984), 115. The estimates of the total number of patentees and of the number of patentees with one patent were calculated by assuming a value of 13,205 patents granted over the period 1751-1852 (as given in Richard J. Sullivan, “England's 'Age of Invention': The Acceleration of Patents and Patentable Invention during the Industrial Revolution," Explorations in Economic History 26 [1989]: 424-52). The remaining columns were obtained by matching our sample of the inventors in the DNB with Bennet Woodcroft, Alphabetical Index of Patents of Invention (London, 1854). The second row ("Alleged patentees $[D N B]$ ") reports the inventors who, according to their DNB entry, obtained at least one British patent, but are not included in Woodcroft's Alphabetical Index (which covers the period 1617-1852), probably because their patents were granted after 1852. There are no consolidated indexes similar to Woodcroft's for the period after 1852.

Maudslay (1771-1831), and Richard Roberts (1789-1864). The compilers could rely on a substantial extant body of literature that documented the achievements of these and other inventors and, more importantly, made an explicit connection between heroic tales of invention and Britain's ascendancy to industrial prowess. ${ }^{35}$

It is important to note that an inventor's patenting practices played a role in his selection. Table 1 displays the patenting behavior of our 383 inventors. A surprisingly high proportion held no patent (39.43 percent in the total $D N B$ sample). This includes some inventors of inherently unpatentable techniques, such as new surgical procedures (most famously,

35. Christine MacLeod, "James Watt, Heroic Invention and the Idea of the Industrial Revolution," in Technological Revolutions in Europe: Historical Perspectives, ed. Maxine Berg and Kristine Bruland (Cheltenham, U.K., 1998), 109-10. By contrast, the fourth cohort (1801-1850) suffers from under-representation both because its members had less time to become famous before the $D N B$ began publication, and because most were born too late to enjoy the hagiographical treatment the Victorians accorded their predecessors when they could be inserted into the grand narrative of the Industrial Revolution. 
Joseph Lister's introduction of antiseptic surgery) or new social inventions (such as Rowland Hill's Penny Post). The majority of nonpatentees, however, had elected not to patent their invention. Evidently, in Britain one could become a "great inventor" without obtaining a patent. By contrast, only ten (6.25 percent) of Khan and Sokoloff's 160 American "great inventors" active between 1790 and 1846 held no patent. ${ }^{36}$ This difference may

OCTOBER

2006

VOL. 47 reflect the relative cheapness and accessibility of the American patent system, which increased the general propensity to patent inventions. ${ }^{37}$ Alternatively, it may owe something to the high esteem in which the British held public-spirited inventors who foreswore intellectual property rights, thereby enhancing their reputation as disinterested benefactors. ${ }^{38}$ As we shall see, humanitarian inventions are over-represented in the DNB by comparison with British patent records, and many inventors included in the DNB achieved various other forms of public recognition. Again, however, the disparity may owe something to the way in which Khan and Sokoloff, when researching their particular sample, conceptualized their inventors as mostly active in fields of patentable inventions.

At the other extreme, the accumulation of a large clutch of patents provided a relatively sure route into the $D N B$. Our sample, particularly in the last two birth cohorts, contains a substantial share of prolific patentees (inventors with six or more patents). In Harry Dutton's terminology, these men formed the emergent group of quasi-professional inventors who could earn a living by inventing, most often by selling and licensing their intellectual property rather than by becoming manufacturers themselves. ${ }^{39}$ Of the approximately 6,100 holders of a single patent, only seventy appear in the DNB; compare this with the twenty-four DNB entries among the fiftyfour holders of eleven or more patents - their names suggested perhaps by R. B. Prosser and H. T. Wood, senior employees of the Patent Office and contributors to the DNB. ${ }^{40}$ Nonetheless, there were some surprising omis-

36. Khan and Sokoloff, “'Schemes of Practical Utility”" (n. 14 above), 290. Curiously, they do not mention how many inventors in their larger sample (1790-1930) held no patents; see Khan and Sokoloff, "Institutions and Democratic Invention."

37. B. Zorina Khan and Kenneth L. Sokoloff, "Patent Institutions, Industrial Organization and Early Technological Change: Britain and the United States, 1790-1850," in Technological Revolutions in Europe, ed. Berg and Bruland, 292-313, esp. 298-99.

38. Examples include Humphry Davy (miner's safety lamp), Edward Jenner (vaccination), Henry Greathead (lifeboat), and Joseph Glass (chimney-sweeping machinery to replace "climbing boys").

39. H. I. Dutton, The Patent System and Inventive Activity during the Industrial Revolution, 1750-1852 (Manchester, 1984), 112-16.

40. John Hewish, Rooms near Chancery Lane: The Patent Office under the Commissioners, 1852-1883 (London, 2000), 59; R. T. Smith, ODNB, s.v. "Wood, Sir Henry Trueman Wright (1845-1929)." Of the forty articles written by Prosser, thirty-two concerned patentees, and of these, seven dealt with patentees who held over ten patents. Wood wrote thirteen articles on inventors for the $D N B$; eleven concerned patentees, of which three covered patentees holding more than ten patents. 
sions of prolific and commercially successful patentees. One was Augustus Applegath (1788-1871), who obtained fifteen patents before 1852, mostly for his printing machinery that revolutionized newspaper production. Another was William Gossage (1799-1877), whose thirteen pre-1852 patents included the "Gossage tower," which reduced air pollution from alkali production. ${ }^{41}$

The field of invention was highly significant. In table 2, we compare the distribution of $D N B$ inventors across technological fields with that of British patentees in this period analyzed by Dutton. Owing to disparate propensities to patent in different fields, the pattern of inventive activity that emerges from the patent records cannot be considered a faithful representation of the overall contours of technological change. ${ }^{42}$ Notwithstanding this fundamental qualification, the comparison is instructive. The relative percentage shares of inventions in the different technological classes for the two complete samples (i.e., all patents 1751-1852, in column 1 of table 2, and all DNB inventors from 1650-1850 in column 2) are represented in figure 1 as a scatter diagram.

By far the largest category of inventions (13 percent) made by the DNB inventors consists of instruments (including scientific and optical instruments, chronometers, clocks and watches, and photographic equipment) ${ }^{43}$ This outcome may be linked to a strong amateur interest in science among the readership of The Athenaeum, which often involved the collection and use of scientific instruments, timepieces, and photographic equipment. Furthermore, since the late seventeenth century, leading clock- and instrument-makers had enjoyed a high degree of public recognition: they signed their products; their shops lined the best streets in London and Bath; many were elected to a fellowship of the Royal Society; and two of the most prominent (George Graham and Thomas Tompion) were buried in Westminster Abbey. ${ }^{44}$

Another well-represented category (especially when compared with the patent record) comprises humanitarian inventions (for example, advances in medicine and surgery, new drugs, lifesaving equipment). Since such advances were often celebrated in the press and popular literature, it is

41. Both men are now deemed of sufficient importance to appear in the Missing Persons volume and the ODNB.

42. Christine MacLeod, Inventing the Industrial Revolution: The English Patent System, 1660-1800 (Cambridge, 1988), 75-157.

43. Medical and surgical instruments are included in a separate ("Humanitarian") category.

44. On the growing public visibility of instrument-makers in the eighteenth century, see Richard Sorrenson, "George Graham, Visible Technician," British Journal for the History of Science 32 (1999): 203-21. For the low propensity to patent in the scientificinstrument trades (which tended to rely chiefly on secrecy), see Petra Moser, "How Do Patent Laws Influence Innovation? Evidence from Nineteenth-Century World's Fairs," American Economic Review 95 (2005): 1214-36. 
TECH NOLOG Y A N C C LTURE

TABLE 2

Types of Invention by All Patents and by Inventors in the DNB

\begin{tabular}{|c|c|c|c|c|c|c|}
\hline $\begin{array}{c}\text { Type } \\
\text { of } \\
\text { invention }\end{array}$ & $\begin{array}{c}\text { All } \\
\text { patents } \\
(1751-1852) \\
(\%)\end{array}$ & $\begin{array}{c}\text { DNB } \\
\text { Total sample } \\
(1650-1850) \\
(\%)\end{array}$ & $\begin{array}{c}\text { DNB } \\
\text { Birth cohort } \\
(1650-1700) \\
(\%)\end{array}$ & $\begin{array}{c}\text { DNB } \\
\text { Birth cohort } \\
(1701-1750) \\
(\%)\end{array}$ & $\begin{array}{c}\text { DNB } \\
\text { Birth cohort } \\
(1751-1800) \\
(\%)\end{array}$ & $\begin{array}{c}\text { DNB } \\
\text { Birth cohort } \\
\text { (1801-1850) } \\
(\%)\end{array}$ \\
\hline Agriculture & $\begin{array}{c}501 \\
(2.93)\end{array}$ & $\begin{array}{c}14 \\
(3.66)\end{array}$ & $\begin{array}{c}1 \\
(3.57)\end{array}$ & $\begin{array}{c}3 \\
(4.17)\end{array}$ & $\begin{array}{c}7 \\
(4.14)\end{array}$ & $\begin{array}{c}3 \\
(2.63)\end{array}$ \\
\hline Chemicals & $\begin{array}{l}1,245 \\
(7.28)\end{array}$ & $\begin{array}{c}15 \\
(3.92)\end{array}$ & $\begin{array}{c}0 \\
(0)\end{array}$ & $\begin{array}{c}2 \\
(2.78)\end{array}$ & $\begin{array}{c}4 \\
(2.37)\end{array}$ & $\begin{array}{c}9 \\
(7.89)\end{array}$ \\
\hline $\begin{array}{l}\text { Communications } \\
\text { (telegraphy, etc.) }\end{array}$ & $\begin{array}{c}106 \\
(0.62)\end{array}$ & $\begin{array}{c}17 \\
(4.44)\end{array}$ & $\begin{array}{c}0 \\
(0)\end{array}$ & $\begin{array}{c}3 \\
(4.17)\end{array}$ & $\begin{array}{c}5 \\
(2.96)\end{array}$ & $\begin{array}{c}9 \\
(7.89)\end{array}$ \\
\hline $\begin{array}{l}\text { Construction } \\
\text { methods }\end{array}$ & $\begin{array}{c}560 \\
(3.27)\end{array}$ & $\begin{array}{c}29 \\
(7.57)\end{array}$ & $\begin{array}{c}1 \\
(3.57)\end{array}$ & $\begin{array}{c}6 \\
(8.33)\end{array}$ & $\begin{array}{c}14 \\
(8.28)\end{array}$ & $\begin{array}{c}8 \\
(7.02)\end{array}$ \\
\hline $\begin{array}{c}\text { Consumer } \\
\text { durables }\end{array}$ & $\begin{array}{l}1,377 \\
(8.05)\end{array}$ & $\begin{array}{c}15 \\
(3.92)\end{array}$ & $\begin{array}{c}1 \\
(3.57)\end{array}$ & $\begin{array}{c}3 \\
(4.17)\end{array}$ & $\begin{array}{c}10 \\
(5.92)\end{array}$ & $\begin{array}{c}1 \\
(0.88)\end{array}$ \\
\hline $\begin{array}{c}\text { Food and } \\
\text { drink }\end{array}$ & $\begin{array}{l}1,149 \\
(6.72)\end{array}$ & $\begin{array}{c}4 \\
(1.04)\end{array}$ & $\begin{array}{c}1 \\
(3.57)\end{array}$ & $\begin{array}{c}0 \\
(0)\end{array}$ & $\begin{array}{c}2 \\
(1.18)\end{array}$ & $\begin{array}{c}1 \\
(0.88)\end{array}$ \\
\hline $\begin{array}{c}\text { Garments } \\
\text { (clothing, hats, } \\
\text { boots, etc.) }\end{array}$ & $\begin{array}{c}738 \\
(4.32)\end{array}$ & $\begin{array}{c}0 \\
(0)\end{array}$ & $\begin{array}{c}0 \\
(0)\end{array}$ & $\begin{array}{c}0 \\
(0)\end{array}$ & $\begin{array}{c}0 \\
(0)\end{array}$ & $\begin{array}{c}0 \\
(0)\end{array}$ \\
\hline $\begin{array}{c}\text { Humanitarian } \\
\text { (drugs, med. } \\
\text { instru., etc.) }\end{array}$ & $\begin{array}{c}289 \\
(1.69)\end{array}$ & $\begin{array}{c}31 \\
(8.09)\end{array}$ & $\begin{array}{c}2 \\
(7.14)\end{array}$ & $\begin{array}{c}8 \\
(11.11)\end{array}$ & $\begin{array}{c}12 \\
(7.10)\end{array}$ & $\begin{array}{c}9 \\
(7.89)\end{array}$ \\
\hline $\begin{array}{c}\text { Instruments } \\
\text { (sci. \& optical } \\
\text { instru., photo.) }\end{array}$ & $\begin{array}{c}355 \\
(2.08)\end{array}$ & $\begin{array}{c}50 \\
(13.05)\end{array}$ & $\begin{array}{c}5 \\
(17.86)\end{array}$ & $\begin{array}{c}15 \\
(20.83)\end{array}$ & $\begin{array}{c}17 \\
(10.06)\end{array}$ & $\begin{array}{c}13 \\
(11.40)\end{array}$ \\
\hline $\begin{array}{l}\text { Machine } \\
\text { tools }\end{array}$ & $\begin{array}{c}124 \\
(0.72)\end{array}$ & $\begin{array}{c}9 \\
(2.35)\end{array}$ & $\begin{array}{c}0 \\
(0)\end{array}$ & $\begin{array}{c}1 \\
(1.39)\end{array}$ & $\begin{array}{c}4 \\
(2.37)\end{array}$ & $\begin{array}{c}4 \\
(3.51)\end{array}$ \\
\hline $\begin{array}{l}\text { Manufacturing } \\
\text { processes (pot- } \\
\text { tery, glass, etc.) }\end{array}$ & $\begin{array}{c}380 \\
(2.22)\end{array}$ & $\begin{array}{c}11 \\
(2.87)\end{array}$ & $\begin{array}{c}3 \\
(10.71)\end{array}$ & $\begin{array}{c}3 \\
(4.17)\end{array}$ & $\begin{array}{c}3 \\
(1.78)\end{array}$ & $\begin{array}{c}2 \\
(1.75)\end{array}$ \\
\hline Metallurgy & $\begin{array}{c}848 \\
(4.96)\end{array}$ & $\begin{array}{c}15 \\
(3.92)\end{array}$ & $\begin{array}{c}2 \\
(7.14)\end{array}$ & $\begin{array}{c}3 \\
(4.17)\end{array}$ & $\begin{array}{c}4 \\
(2.37)\end{array}$ & $\begin{array}{c}6 \\
(5.26)\end{array}$ \\
\hline $\begin{array}{c}\text { Military } \\
\text { (weapons, etc.) }\end{array}$ & $\begin{array}{c}275 \\
(1.61)\end{array}$ & $\begin{array}{c}19 \\
(4.96)\end{array}$ & $\begin{array}{c}2 \\
(7.14)\end{array}$ & $\begin{array}{c}2 \\
(2.78)\end{array}$ & $\begin{array}{c}6 \\
(3.55)\end{array}$ & $\begin{array}{c}9 \\
(7.89)\end{array}$ \\
\hline $\begin{array}{l}\text { Mining (venti- } \\
\text { lators, drainage, } \\
\text { safety lamps) }\end{array}$ & $\begin{array}{c}603 \\
(3.51)\end{array}$ & $\begin{array}{c}6 \\
(1.57)\end{array}$ & $\begin{array}{c}0 \\
(0)\end{array}$ & $\begin{array}{c}0 \\
(0)\end{array}$ & $\begin{array}{c}5 \\
(2.96)\end{array}$ & $\begin{array}{c}1 \\
(0.88)\end{array}$ \\
\hline $\begin{array}{l}\text { Nonsteam power } \\
\text { gen. (water- } \\
\text { wheels, wind- } \\
\text { mills, electric } \\
\text { motors) }\end{array}$ & $\begin{array}{c}2,257 \\
(13.20)\end{array}$ & $\begin{array}{c}17 \\
(4.44)\end{array}$ & $\begin{array}{c}0 \\
(0)\end{array}$ & $\begin{array}{c}3 \\
(4.17)\end{array}$ & $\begin{array}{c}5 \\
(2.96)\end{array}$ & $\begin{array}{c}9 \\
(7.89)\end{array}$ \\
\hline $\begin{array}{l}\text { Nontextiles } \\
\text { prod. machinery } \\
\text { (printing, etc.) }\end{array}$ & $\begin{array}{c}661 \\
(3.87)\end{array}$ & $\begin{array}{c}18 \\
(4.70)\end{array}$ & $\begin{array}{c}1 \\
(3.57)\end{array}$ & $\begin{array}{c}1 \\
(1.39)\end{array}$ & $\begin{array}{c}13 \\
(7.69)\end{array}$ & $\begin{array}{c}3 \\
(2.63)\end{array}$ \\
\hline $\begin{array}{l}\text { Prod. machinery } \\
\quad \text { (textiles) }\end{array}$ & $\begin{array}{l}1,872 \\
(10.9)\end{array}$ & $\begin{array}{c}26 \\
(6.79)\end{array}$ & $\begin{array}{c}2 \\
(7.14)\end{array}$ & $\begin{array}{c}11 \\
(15.28)\end{array}$ & $\begin{array}{c}8 \\
(4.73)\end{array}$ & $\begin{array}{c}5 \\
(4.39)\end{array}$ \\
\hline
\end{tabular}


TABLE 2 (continued)

\begin{tabular}{|c|c|c|c|c|c|c|}
\hline $\begin{array}{c}\text { Type } \\
\text { of } \\
\text { invention }\end{array}$ & $\begin{array}{c}\text { All } \\
\text { patents } \\
(1751-1852) \\
(\%)\end{array}$ & $\begin{array}{c}\text { DNB } \\
\text { Total sample } \\
(1650-1850) \\
(\%)\end{array}$ & $\begin{array}{c}\text { DNB } \\
\text { Birth cohort } \\
(1650-1700) \\
(\%)\end{array}$ & $\begin{array}{c}\text { DNB } \\
\text { Birth cohort } \\
(1701-1750) \\
(\%)\end{array}$ & $\begin{array}{c}\text { DNB } \\
\text { Birth cohort } \\
(1751-1800) \\
(\%)\end{array}$ & $\begin{array}{c}\text { DNB } \\
\text { Birth cohort } \\
(1801-1850) \\
(\%)\end{array}$ \\
\hline Steam engines & $\begin{array}{l}1,053 \\
(6.13)\end{array}$ & $\begin{array}{c}27 \\
(7.05)\end{array}$ & $\begin{array}{c}5 \\
(17.86)\end{array}$ & $\begin{array}{c}2 \\
(2.78)\end{array}$ & $\begin{array}{c}17 \\
(10.06)\end{array}$ & $\begin{array}{c}3 \\
(2.63)\end{array}$ \\
\hline $\begin{array}{l}\text { Transport } \\
\text { (maritime) }\end{array}$ & $\begin{array}{l}1,135 \\
(6.64)\end{array}$ & $\begin{array}{c}36 \\
(9.40)\end{array}$ & $\begin{array}{c}2 \\
(7.14)\end{array}$ & $\begin{array}{c}5 \\
(6.94)\end{array}$ & $\begin{array}{c}19 \\
(11.24)\end{array}$ & $\begin{array}{c}10 \\
(8.77)\end{array}$ \\
\hline $\begin{array}{l}\text { Transport } \\
\text { (railways) }\end{array}$ & $\begin{array}{c}914 \\
(5.34)\end{array}$ & $\begin{array}{c}15 \\
(3.92)\end{array}$ & $\begin{array}{c}0 \\
(0)\end{array}$ & $\begin{array}{c}0 \\
(0)\end{array}$ & $\begin{array}{c}10 \\
(5.92)\end{array}$ & $\begin{array}{c}5 \\
(4.39)\end{array}$ \\
\hline $\begin{array}{c}\text { Transport } \\
\text { (other) }\end{array}$ & $\begin{array}{c}659 \\
(3.84)\end{array}$ & $\begin{array}{c}9 \\
(2.35)\end{array}$ & $\begin{array}{c}0 \\
(0)\end{array}$ & $\begin{array}{c}1 \\
(1.39)\end{array}$ & $\begin{array}{c}4 \\
(2.37)\end{array}$ & $\begin{array}{c}4 \\
(3.51)\end{array}$ \\
\hline TOTAL & $\begin{array}{c}17,101 \\
(100)\end{array}$ & $\begin{array}{c}383 \\
(100)\end{array}$ & $\begin{array}{c}28 \\
(100)\end{array}$ & $\begin{array}{c}72 \\
(100)\end{array}$ & $\begin{array}{c}169 \\
(100)\end{array}$ & $\begin{array}{c}114 \\
(100)\end{array}$ \\
\hline
\end{tabular}

Note: Percentage shares are given in parentheses. The source for the second column ("All patents [1751-1852]") is H. I. Dutton, The Patent System and Inventive Activity during the Industrial Revolution, 1750-1852 (Manchester, 1984), 206-8. We have aggregated Dutton's data into broader categories. Dutton used the Abridgements of Specifications, which led to some double counting: this produced a total of 17,101, compared with the actual total of 13,205 patents, as calculated by Richard J. Sullivan ("England's 'Age of Invention': The Acceleration of Patents and Patentable Invention during the Industrial Revolution," Explorations in Economic History 26 [1989]: 424-52). For classifying the DNB inventors, we have used the most famous invention of the inventor in question (according to the entry in the $D N B)$.

unsurprising that they attracted the DNB's attention. Not even the promoters of proprietary medicines, who keenly exploited the publicity value of patents especially in the later eighteenth century, managed to redress this imbalance. $^{45}$

Further, our sample of $D N B$ inventors is dominated by the "big science and engineering" achievements that characterize the traditional narratives of the British Industrial Revolution-in particular, steam engines, construction methods, and textile machinery-and by the tools of empire (maritime transport, weaponry, and the newly emerging communication technologies). ${ }^{46}$ All these categories (with the exception of textile machinery and railways) are better represented in the $D N B$ than in the patent records. This suggests that the DNB's compilers were drawn to the more glamorous and novel inventions of mechanical and military hardware. In other words, inventors associated with the technological icons of imperialism and the Industrial Revolution were much more visible than others.

45. MacLeod, Inventing the Industrial Revolution, 84-88.

46. Daniel R. Headrick, The Tools of Empire: Technology and European Imperialism in the Nineteenth Century (Oxford, 1981). The impact of the developments in communication technologies on Victorian techno-scientific culture is discussed in Iwan R. Morus, "'The Nervous System of Britain': Space, Time and the Electric Telegraph in the Victorian Age," British Journal for the History of Science 33 (2000): 455-75. On the cultural construction of steam power, railways, steam navigation, and telegraphy as technological icons of progress in nineteenth-century Britain, see Crosbie Smith and Ben Marsden, Engineering Empires: A Cultural History of Technology in Nineteenth-Century Britain (New York, 2005). 
OCTOBER

2006

VOL. 47

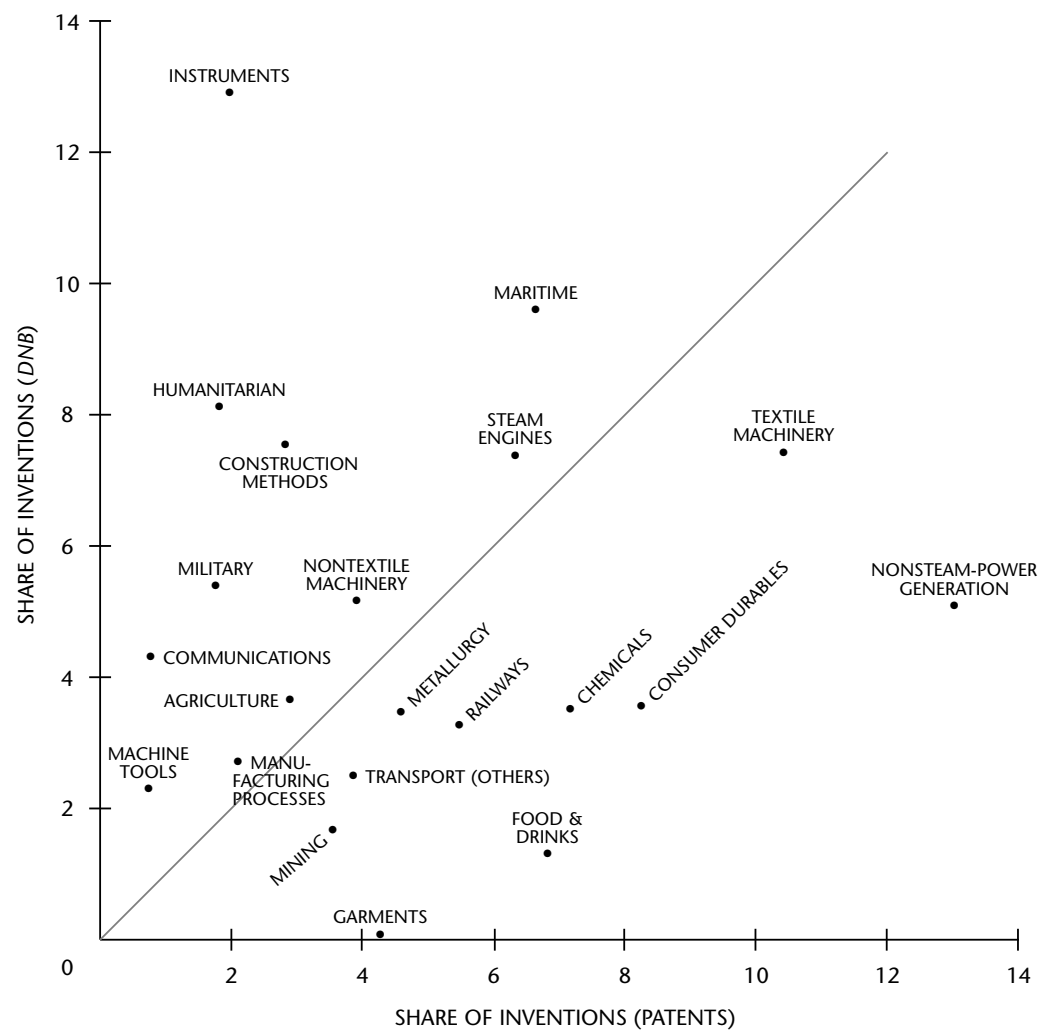

FIG. 1 Shares of patent inventions plotted against $D N B$ inventions. The coefficient of correlation between the two variables is -0.0111 and is not statistically significant (at $p<10$ percent). The diagonal line represents the relation $y=x$. Observations above the line have a higher share of DNB inventions than patents; and vice versa, observations below the line have a higher share of patents than DNB inventions. (Source: Table 2.)

By contrast, while the patent records exhibit a sizable share of inventions in consumer goods (consumer durables, 8 percent; food and drink, nearly 7 percent; garments, 4.3 percent), the DNB sample is characterized by much smaller proportions (respectively 3.9 percent, 1 percent, and zero). The $D N B$ 's disregard for this large field of domestic inventions helps to explain its omission of female inventors, for whom this was a major sphere of activity. The patent records also reorient priorities within the field of transport, recognizing the importance still attached to road transport. For example, while patents for improvements to carriages were legion, they did not provide a route to fame or entry into the DNB (the exception being Joseph Hansom and his cab). Power generation shows a similar pattern: the patents reduce slightly the dominance of steam found in the $D N B$, but elevate 
markedly the significance of other forms of power production (namely, water, wind, gas, and, increasingly, electricity). ${ }^{47}$ Finally, the $D N B$ halves the importance accorded by the patent statistics to the invention of chemicals (a field that included many textile-related inventions such as bleaching and dyeing).$^{48}$ In summary, we may say that an inventor was more likely to become "great" (i.e., be included in the $D N B$ ) if he were engaged in the more prestigious modern technologies than in other (older or more feminine) spheres.

Table 3 displays the social class of the DNB's inventors, classified by primary occupation. Two points merit attention: first, the distribution is skewed toward the middle classes. In particular, the establishment of a successful manufacturing enterprise tended to bring an inventor to public attention; the fame, for example, of Watt, Wedgwood, and Arkwright is itself testimony to this tendency. By analogy, it is possible that Khan and Sokoloff's sample of American "great inventors" is similarly biased toward successful entrepreneurs. Second, the increasing representation of inventors in the emerging engineering professions and the corresponding decline of skilled workers over time may reflect a growing awareness of the activities of professional engineers. ${ }^{49}$

Table 4 reports the national awards and honors obtained by the DNB's inventors during their lifetime. The last two cohorts reaped most of these rewards. This is not surprising, as it was only during the second half of the nineteenth century that the state began to confer honors on inventors, especially favoring those active in the fields of armaments and communications. ${ }^{50}$ We must inquire how far these honors were indicative of truly "great" achievers, and whether these inventors' social elevation prompted their inclusion. Similarly, throughout the entire period, though at its highest in the final cohort, a fairly consistent share of $D N B$ inventors was elected

47. Contemporaries tended to conflate the early development of steam technology with its economic significance. These exaggerated judgments were frequently rehearsed in major historical works on the British Industrial Revolution; see, in particular, Walt W. Rostow, The Stages of Economic Growth (Cambridge, 1960). For a detailed appraisal of the (limited) economic impact of the diffusion of the steam engine during the early phases of industrialization, see G. N. von Tunzelmann, Steam Power and British Industrialization to 1860 (Oxford, 1978). On the powerful influence of developments in steampower technology in nineteenth-century accounts of economic and social change, see Dolores Greenberg, "Energy, Power, and Perceptions of Social Change in the Early Nineteenth Century," American Historical Review 95 (1990): 693-714.

48. This was somewhat corrected by the Missing Persons volume, which included twelve inventors of chemical processes and equipment.

49. See, however, the strong emergence of engineers as patentees during 1850-1870, reported in Ian Inkster, "Engineers as Patentees and the Cultures of Invention, 18301914 and Beyond: The Evidence from the Patent Data," Quaderns d'Historia de l'Enginyeria 6 (2004): 1-27.

50. MacLeod, Heroes of Invention (n. 7 above), chap. 8. 
TABLE 3

SOCIAL CLASS OF DNB INVENTORS, 1650-1850

\begin{tabular}{|c|c|c|c|c|c|}
\hline Social class & $\begin{array}{c}\text { DNB } \\
\text { Total sample } \\
(1650-1850) \\
\text { (\%) }\end{array}$ & $\begin{array}{c}\text { DNB } \\
\text { Birth cohort } \\
(1650-1700) \\
\text { (\%) }\end{array}$ & $\begin{array}{c}\text { DNB } \\
\text { Birth cohort } \\
(1701-1750) \\
(\%)\end{array}$ & $\begin{array}{c}\text { DNB } \\
\text { Birth cohort } \\
(1751-1800) \\
(\%)\end{array}$ & $\begin{array}{c}\text { DNB } \\
\text { Birth cohort } \\
(1801-1850) \\
(\%)\end{array}$ \\
\hline Upper class (nobility, gentry) & $\begin{array}{c}4 \\
(1.04)\end{array}$ & $\begin{array}{c}1 \\
(3.57)\end{array}$ & $\begin{array}{c}0 \\
(0)\end{array}$ & $\begin{array}{c}2 \\
(1.18)\end{array}$ & $\begin{array}{c}1 \\
(0.88)\end{array}$ \\
\hline $\begin{array}{l}\text { Established professions (doc- } \\
\text { tors, lawyers, military officers, } \\
\text { university professors, etc.) }\end{array}$ & $\begin{array}{c}133 \\
(34.73)\end{array}$ & $\begin{array}{c}12 \\
(42.86)\end{array}$ & $\begin{array}{c}25 \\
(34.72)\end{array}$ & $\begin{array}{c}56 \\
(33.14)\end{array}$ & $\begin{array}{c}40 \\
(35.09)\end{array}$ \\
\hline $\begin{array}{l}\text { Finance and trade } \\
\text { (bankers, merchants, etc.) }\end{array}$ & $\begin{array}{c}11 \\
(2.87)\end{array}$ & $\begin{array}{c}0 \\
(0)\end{array}$ & $\begin{array}{c}1 \\
(1.39)\end{array}$ & $\begin{array}{c}8 \\
(4.73)\end{array}$ & $\begin{array}{c}2 \\
(1.75)\end{array}$ \\
\hline $\begin{array}{l}\text { Engineering professions } \\
\text { (civil \& consulting engineers) }\end{array}$ & $\begin{array}{c}78 \\
(20.37)\end{array}$ & $\begin{array}{c}0 \\
(0)\end{array}$ & $\begin{array}{c}7 \\
(9.72)\end{array}$ & $\begin{array}{c}35 \\
(20.71)\end{array}$ & $\begin{array}{c}36 \\
(31.58)\end{array}$ \\
\hline Industrialists & $\begin{array}{c}98 \\
(25.59)\end{array}$ & $\begin{array}{c}7 \\
(25)\end{array}$ & $\begin{array}{c}18 \\
(25)\end{array}$ & $\begin{array}{c}44 \\
(26.04)\end{array}$ & $\begin{array}{c}29 \\
(25.44)\end{array}$ \\
\hline $\begin{array}{l}\text { Skilled workmen } \\
\text { (instrument-makers, silk } \\
\text { weavers, "artisans," etc.) }\end{array}$ & $\begin{array}{c}52 \\
(13.58)\end{array}$ & $\begin{array}{c}6 \\
(21.43)\end{array}$ & $\begin{array}{c}20 \\
(27.78)\end{array}$ & $\begin{array}{c}21 \\
(12.43)\end{array}$ & $\begin{array}{c}5 \\
(4.39)\end{array}$ \\
\hline Agriculture & $\begin{array}{c}7 \\
(1.83)\end{array}$ & $\begin{array}{c}2 \\
(7.14)\end{array}$ & $\begin{array}{c}1 \\
(1.39)\end{array}$ & $\begin{array}{c}3 \\
(1.78)\end{array}$ & $\begin{array}{c}1 \\
(0.88)\end{array}$ \\
\hline TOTAL & $\begin{array}{c}383 \\
(100)\end{array}$ & $\begin{array}{c}28 \\
(100)\end{array}$ & $\begin{array}{c}72 \\
(100)\end{array}$ & $\begin{array}{c}169 \\
(100)\end{array}$ & $\begin{array}{c}114 \\
(100)\end{array}$ \\
\hline
\end{tabular}

Note: Percentage shares are reported in parentheses. Source: DNB.

to the Royal Society, a presence that indicates the existence of persistently porous boundaries between science and technology. ${ }^{51}$

Finally, there was a rise in (and between) the last two cohorts of inventors who belonged to the two major engineering societies of the time, the Institution of Civil Engineers (founded in 1818 in London) and the Institution of Mechanical Engineers (founded in 1847 in Birmingham). ${ }^{52}$ Being dependent on co-option, the membership of these two associations was based on some degree of professional distinction. Of course, it had not been available to the first cohort nor to any but the most long-lived of the second. In all our categories of awards and honors (except Parliamentary

51. The attitude of the members of the Royal Society toward the practical applications of scientific advances is discussed by Larry Stewart, The Rise of Public Science: Rhetoric, Technology and Natural Philosophy in Newtonian Britain, 1660-1750 (Cambridge, 1992); and David Philip Miller, "The Usefulness of Natural Philosophy: The Royal Society and the Culture of Practical Utility in the Later Eighteenth Century," British Journal for the History of Science 32 (1999): 185-201.

52. For a condensed historical outline of the two institutions and their roles in the expansion and consolidation of the engineering profession in Britain, see Buchanan (n. 5 above), 69-87. 
AWARDS AND HONORS OF DNB INVENTORS, 1650-1850

\begin{tabular}{|c|c|c|c|c|c|}
\hline Awards and honors & $\begin{array}{c}\text { DNB } \\
\text { Total sample } \\
(1650-1850) \\
\text { (\%) }\end{array}$ & $\begin{array}{c}\text { DNB } \\
\text { Birth cohort } \\
(1650-1700) \\
\text { (\%) }\end{array}$ & $\begin{array}{c}\text { DNB } \\
\text { Birth cohort } \\
(1701-1750) \\
(\%)\end{array}$ & $\begin{array}{c}\text { DNB } \\
\text { Birth cohort } \\
(1751-1800) \\
(\%)\end{array}$ & $\begin{array}{c}\text { DNB } \\
\text { Birth cohort } \\
(1801-1850) \\
(\%)\end{array}$ \\
\hline Peerage & $\begin{array}{c}5 \\
(1.31)\end{array}$ & $\begin{array}{c}0 \\
(0)\end{array}$ & $\begin{array}{c}0 \\
(0)\end{array}$ & $\begin{array}{c}1 \\
(0.59)\end{array}$ & $\begin{array}{c}4 \\
(3.51)\end{array}$ \\
\hline Knighthood or baronetcy & $\begin{array}{c}44 \\
(11.49)\end{array}$ & $\begin{array}{c}1 \\
(3.57)\end{array}$ & $\begin{array}{c}1 \\
(1.39)\end{array}$ & $\begin{array}{c}21 \\
(12.43)\end{array}$ & $\begin{array}{c}21 \\
(18.42)\end{array}$ \\
\hline Rewarded by Parliament & $\begin{array}{c}8 \\
(2.09)\end{array}$ & $\begin{array}{c}1 \\
(3.57)\end{array}$ & $\begin{array}{c}2 \\
(2.78)\end{array}$ & $\begin{array}{c}5 \\
(2.96)\end{array}$ & $\begin{array}{c}0 \\
(0)\end{array}$ \\
\hline Fellow of the Royal Society & $\begin{array}{c}78 \\
(20.37)\end{array}$ & $\begin{array}{c}6 \\
(21.43)\end{array}$ & $\begin{array}{c}16 \\
(22.22)\end{array}$ & $\begin{array}{c}25 \\
(14.79)\end{array}$ & $\begin{array}{c}31 \\
(27.19)\end{array}$ \\
\hline $\begin{array}{l}\text { Member of the Institution } \\
\text { of Civil Engineers } \\
\text { (founded 1818) }\end{array}$ & $\begin{array}{c}50 \\
(13.05)\end{array}$ & $\begin{array}{c}0 \\
(0)\end{array}$ & $\begin{array}{c}0 \\
(0)\end{array}$ & $\begin{array}{c}23 \\
(13.61)\end{array}$ & $\begin{array}{c}27 \\
(23.68)\end{array}$ \\
\hline $\begin{array}{l}\text { Member of the Institution } \\
\text { of Mechanical Engineers } \\
\text { (founded 1847) }\end{array}$ & $\begin{array}{c}17 \\
(4.44)\end{array}$ & $\begin{array}{c}0 \\
(0)\end{array}$ & $\begin{array}{c}0 \\
(0)\end{array}$ & $\begin{array}{c}5 \\
(2.96)\end{array}$ & $\begin{array}{c}12 \\
(10.53)\end{array}$ \\
\hline $\begin{array}{l}\text { Others (medalists of the Soci- } \\
\text { ety of Arts, members of other } \\
\text { scientific institutions, etc.) }\end{array}$ & $\begin{array}{c}41 \\
(10.70)\end{array}$ & $\begin{array}{c}2 \\
(7.14)\end{array}$ & $\begin{array}{c}6 \\
(8.33)\end{array}$ & $\begin{array}{c}16 \\
(9.47)\end{array}$ & $\begin{array}{c}17 \\
(14.91)\end{array}$ \\
\hline None & $\begin{array}{c}213 \\
(55.61)\end{array}$ & $\begin{array}{c}19 \\
(67.86)\end{array}$ & $\begin{array}{c}49 \\
(68.06)\end{array}$ & $\begin{array}{c}101 \\
(59.76)\end{array}$ & $\begin{array}{c}44 \\
(38.6)\end{array}$ \\
\hline TOTAL & 458 & 29 & 74 & 197 & 158 \\
\hline
\end{tabular}

Note: Percentage shares are reported in parentheses. These have been calculated with respect to the total numbers of inventors in each period. Since an inventor could receive more than one award during his career (William Thompson, for example, became both a Fellow of the Royal Society and a peer), the total sums reported here do not correspond to those given in tables 2 and 3. Source: $D N B$.

rewards), the fourth cohort is always the most prominent. ${ }^{53}$ While consistent with the growing public respect for inventors in the second half of the nineteenth century, this may also indicate a further bias in the selection: such national recognition helped a few to stand out from the crowd of contemporary inventors and patentees.

Inclusion in the $D N B$ was not restricted to the great and good, however. The Dictionary was characterized by its "remarkable eclecticism": it contained a "legion of minor figures." 54 Not only did Stephen contend that "it is the second-rate people that provide the really useful reading," but he was also concerned to give notoriety its due, to include the criminal as well as the saint. ${ }^{55}$

53. Until the early nineteenth century, Parliament was occasionally persuaded to grant a pecuniary reward to an especially deserving inventor.

54. Mark Curthoys, "Modern Britain," in Oxford Dictionary of National Biography (publicity leaflet [c. 2004]).

55. Quoted in Cannadine, "British Worthies" (n. 2 above), 6. Lee, however, was "more 
OCTOBER

2006

VOL. 47

Consequently, it is unsurprising that our list of inventors accommodates eccentricity and quirkiness. It includes Richard James Morrison (17951874), who proposed various contrivances to the Admiralty, but was "chiefly remarkable . . f for his devotion . . to the pseudo-science of Astrology." Another entry immortalizes John Austin (active 1820), "a Scotch inventor" known mainly by his publication of shorthand systems, including "A System of Stenographic Music" for the easy transcription of music as it was played.

\section{Concluding Remarks}

Our study suggests that, far from being a representative sample of people active in the field of invention, the inventors who appear in the DNB reflect various Victorian biases and preconceptions about the role of technology in the transformation of contemporary society. As a consequence, the use of collective biographies as a source for the history of technology is open to at least two serious pitfalls. First, it risks the uncritical reproduction of preconceptions about the identity of the inventor that were current at the time of their compilation. In this sense, biographical dictionaries might actually reveal more about the lenses through which scholars and contemporaries have looked at and judged particular phenomena than about the properties of the phenomena themselves. Second, it may overemphasize the role of individual inventors and thereby help to perpetuate a heroic conception of technological change by neglecting the continuous transformation of technologies during their ordinary use. Economic historians such as Landes, Mathias, and Rosenberg have long insisted on the significance of less visible and anonymous streams of incremental innovation during the early phases of industrialization. ${ }^{56}$ Over at least the last twenty years, this emphasis has led to the adoption in the innovation-studies literature of a perspective that explicitly considers inventive activities as collective endeavors. Attention is increasingly focused on communities of inventors (sharing specific cognitive frames) engaged in the generation and exploitation of technological opportunities. This perspective, inspired by T. S. Kuhn's philosophy of science, clearly emphasizes the social basis of inventive activities, but it is also able to account for ruptures and discontinuities, with individual inventors or, more often, small nonconformist groups of initiators playing a critical role in the

establishment minded" and tried to restrict the DNB to the more distinguished (Thomas [n. 3 above], 30-31). See also Matthew (n. 3 above), 11; and W. N. Medlicott, "Contemporary History in Biography," Journal of Contemporary History 7 (1972): 91-106, esp. 95.

56. David S. Landes, The Unbound Prometheus: Technological Change and Industrial Development in Western Europe from 1750 to the Present (Cambridge, 1969); Peter Mathias, The First Industrial Nation: An Economic History of Britain, 1700-1914 (London, 1969); and Nathan Rosenberg, Perspectives on Technology (Cambridge, 1976). 
emergence and consolidation of novel technological paradigms. ${ }^{57}$ Furthermore, it could be argued that recent developments in the history of technology, by constructing narratives in which a wider set of actors-in particular, users - is collectively involved in the process of technological change, are leading us to question the very category of the inventor itself. ${ }^{58}$ Perhaps a more suitable application of prosopography may lie in the detailed exploration of the broad communities of actors involved in the emergence and consolidation of specific technologies, rather than in the analysis of aggregate populations of inventors, engineers, or scientists.

A further hazard, at least in Britain, is the uncritical perpetuation of the Victorians' conception of the Industrial Revolution. Those historians who argue that the traditional narrative of British industrialization is unduly concentrated on particular industries and technologies will consider the biases in the DNB's selection of inventors as part of a major historiographical problem. Compilers were attracted by major advances in industrial machinery and prestigious engineering projects; and, as we have seen, the DNB exemplifies the historical neglect of consumer industries to which Maxine Berg has called our attention..$^{59}$ While personal anxieties about health or particular amateur interests may have predisposed the compilers to take notice of medical advances or examples of the instrument- and clock-makers' ingenious arts, inventions that pertained to home comforts and personal appearance (considered to belong to the feminine sphere) were largely taken for granted.

Yet, the $D N B$ also downplays those major economic activities, no matter how innovative, that did not belong to the nineteenth-century narratives of industrialization and empire. Reminding us that the food and drink industries "were the largest single complex of economic activity; [and] ... remained so during the nineteenth century," Kristine Bruland highlights five major areas of technological change affecting them. ${ }^{60}$ Significantly,

57. Edward W. Constant II, The Origins of the Turbojet Revolution (Baltimore, 1980), chap. 1; Giovanni Dosi, "Technological Paradigms and Technological Trajectories," Research Policy 11 (1982): 147-62; and Christopher Freeman, "The Economics of Technical Change," Cambridge Journal of Economics 18 (1994): 463-514.

58. For an overview and discussion, see John Staudenmaier, S.J., "Rationality, Agency, Contingency: Recent Trends in the History of Technology," Research in American History 30 (2002): 168-81. On the role of users in technological evolution, see David Edgerton, "From Innovation to Use: Ten (Eclectic) Theses on the Historiography of Technology," History and Technology 16 (1999): 1-26.

59. Maxine Berg, "Product Innovation in Core Consumer Industries in EighteenthCentury Britain," in Technological Revolutions in Europe, ed. Berg and Bruland (n. 35 above), $138-57$.

60. Kristine Bruland, "Industrialisation and Technological Change," in The Cambridge Economic History of Modern Britain, vol. 1, ed. Roderick Floud and Paul Johnson (Cambridge, 2004), 117-46, esp. 129. On the economic significance of the food industry in the early Victorian economy, see Sarah Horrell, Jane Humphries, and Martin Weale, "An Input-Output Table for 1841," Economic History Review 47 (1994): 545-66. 
OCTOBER

2006

VOL. 47 only one of the inventors she mentions received an entry in the $D N B$, the exception being Admiral Sir Isaac Coffin (1759-1839) whose inventive achievement, the "perpetual oven" for baking bread on a large scale, is not mentioned in his entry. Similarly, except for inventors of optical glass, the highly innovative glass industry is regularly ignored by both the standard narratives and the $D N B{ }^{61}$

In summary, then, our discussion of the biases in the DNB's treatment of inventors and inventive activities resonates with some recent pleas to reconsider the multifarious technological dimensions of the British Industrial Revolution. ${ }^{62}$ This should involve a careful reassessment of the technological dynamism of sectors and locations that have so far been left at the margins of traditional narratives, which tend to concentrate on a handful of glamorous technologies. It is time to call from the back of the stage the anonymous crowd that has found no place in the heroic tales of invention told to us by the late Victorians. ${ }^{63}$
61. Bruland, "Industrialisation and Technological Change," 133-34.

62. Maxine Berg and Pat Hudson, "Rehabilitating the Industrial Revolution," Economic History Review 65 (1992): 24-50; Maxine Berg, The Age of Manufactures, 1700-1820: Industry, Innovation and Work in Britain, 2nd ed. (London, 1994), esp. 28-30; and Bruland, "Industrialisation and Technological Change," 145-46.

63. For recent moves in this direction, see A. P. Woolrich, "The London Engineering Industry at the Time of Maudslay," in Henry Maudslay and the Pioneers of the Machine Age, ed. John Cantrell and Gillian Cookson (London, 2002), 94-108; Clive Behagg, "Mass Production without the Factory: Craft Producers, Guns and Small Firm Innovation, 1790-1815," Business History 40 (1998): 1-15; Gillian Cookson, "Family Firms and Business Networks: Textile Engineering in Yorkshire, 1780-1830," Business History 39 (1997): 1-20; and Alessandro Nuvolari, "Collective Invention during the British Industrial Revolution: The Case of the Cornish Pumping Engine," Cambridge Journal of Economics 28 (2004): 347-63. 